\title{
Determinants of procurement strategy for construction works: quantity surveyors' perspectives
}

\author{
AbdulLateef Olanrewaju1, a , Paul Junior Anavhe ${ }^{2}$, Abdul Rashid Abdul Aziz ${ }^{3}$, Chu Hui Chen ${ }^{1}$, and Wai Soon Han ${ }^{1}$ \\ ${ }^{1}$ Universiti Tunku Abdul Rahman, 31900 Kampar, Perak, Malaysia \\ ${ }^{2}$ CDP Partnership Ltd, 3 Borno Road, Kaduna, Nigeria \\ ${ }^{3}$ Universiti Sains Malaysia, Penang, Malaysia
}

\begin{abstract}
The selection of the 'appropriate' procurement strategy is a prerequisite to the success or failure of a construction project. This paper investigates the factors determining the selection of appropriate procurement strategy for construction works in Nigeria. Data for the study was collected through an online survey questionnaire. The survey administration involves only quantity surveyors. Quantity surveyors were targeted because they advise clients and other stakeholders on procurement and contractual issues on construction works. A total of 33 usable responses were received and analysed for this study. On the basis of the results, it is concluded that the selection of procurement strategies for construction depend on complex interrelated factors. The study could not detect a particular factor or few factors responsible for a procurement strategy selection. The findings of this study is useful because it argues that the construction sector needs to broaden its considerations on the procurement strategy's determinants rather than focusing solely on the client's type and nature of projects as is often cited. Future research could segment these factors in terms of class of construction works or increase the sample size, which might lead to different findings.
\end{abstract}

\section{Introduction}

This paper is part of on an ongoing research focusing on construction procurement planning in Nigeria. Construction procurement is defined as the entire process in the delivery of the built facilities, from the point the client decides to build/construct to when the facility is in operation [1]. Construction procurement comprises many stakeholders such as clients, design professionals, construction professionals, and operational team. The major professionals in the construction sector involved in the procurement process include engineers, quantity surveyors, and architects. It had been argued that the procurement aspect of the project delivery processes is critical for the construction sector to deliver value for money. For instance, after analysing various reports $[2,3$, 4] on the construction sectors including it was cited that if the construction sectors were to improve, it would stem from the procurement process [1]. While the process involved in the selection of a suitable procurement strategy is crucial, the purpose of this current study is to determine the factors accounting for the selection of a strategy for construction works.

The current research is different from existing known research because it examines these determinants from the procurement 'experts' themselves rather than questioning all the professionals or stakeholders involved in the construction sectors. For instance, in Nigeria, Dada [5] and Ojo and Ikpo [6] investigated utility factors for

\footnotetext{
a Corresponding author: abdullateef.olanrewaju@ymail.com
}

procurement involving various stakeholders in the sectors. In South Africa, Mathonsi, and Thwala [7] included all the professionals in the construction sector. In Australia, Love et al. [8] sampled various construction professionals and clients to determine the determinants of procurement selections. However, considering the expertise, competencies, and skills of the quantity surveyors it is contended that they are in a better position to provide valid and unbiased information on procurement related issues in the construction sector. The salient concern is to prevent the results to suffer from the 'averaging' process prevalent in the existing research. Even if industry-specific data is collected, the heterogeneity of the professionals could not be accounted for because they will be 'grounded' in the results. Therefore, the study aims to provide fresh knowledge on procurement issues. The remaining parts of the paper are structured as follows. The second part of the paper presents an overview of the significance of the construction sector. The third part highlights issues in construction procurement strategies. In section four, the skills, competencies, and roles of quantity surveyors are provided. Section five addresses itself to the research design. Section six focuses on the presentation of results and discussion. The summary of the study is presented in section seven. 


\section{Overview of the Nigerian construction sector}

The Nigerian construction sector provides almost $70 \%$ of the fixed capital formation. In 2012, the construction industry contributed N2, $188,718.59$ million, $3.05 \%$ to the GDP and employed 6,913,536 people [9]. However, this figure is not static as it could increase or decrease due to the peculiar nature of the construction sector. It could be more if the labour force from the allied industries that produce, process, and transport construction materials, components, and services are added. The Nigerian construction sector is largely British with some incursion from Europe and America as such quantity surveying is offered in most of major universities and polytechnics. While poor service delivery of the construction projects is caused by various factors, the procurement strategy that is used to procure the projects has a profound influence on the success of projects. The focus of the sector is to achieve the values system set by a client. A client's value system is a logical set of values agreed and/or developed by a person, organisation, business, or society as a rule to guide its behaviour and decision preferences in all situations. The client value system depends on the experience, nature of business, and background of the client. For construction works, the client value system defines the worthiness and desirability of a construction to a client $[10,11]$. The worthiness and desirability is measured by different criteria including function, quality, aesthetic, time, safety, reliability, time, capital cost, operating cost, sustainability, resale or rental value, flexibility, comfort, community, esteem, and politics. Various researches indicate that the selection of appropriate procurement alternative is crucial for the achievement of the client value system in a project and the performance of the entire construction sector. However, the performance of the Nigerian construction sector often suffers from delays in project completion, cost overrun, poor quality, high incidence of collapse buildings and bridges, and high maintenance cost [1].

\section{Procurement strategies determinants}

and

There are proliferations of definitions for the term procurement, even within the construction sector. Here, construction procurement is defined as all the processes and activities involved in the delivery of the built facility from the point a client decides to build/construct to when the facility is in operation [1]. This provides that the procurement processes for a project, ranges from planning, designing as well as construction or maintenance of a project. The processes of procurement are not however, a pure science. The skills require of a procurement experts cover history, politics, economic, psychology, engineering, management, business, technology, administration, sociology as well as science. When construction is required, the next step is to decide on the suitable procurement method. Construction procurement method is the step, direction and procedure involve in acquiring a 'construction work'. The construction could be new facility or existing completed facility, maintenance services, refurbishment, renovation or rehabilitation. One type of method is not suitable for all clients. In Table 1 is the most cited methods [see also: $8,10,13]$. The table will guides readers in identifying a suitable for a construction work.

According to Perry (1985), procurement could generally be typified into design separated from construction and design combined with construction [12]. The various types of procurement strategies reflect the extent to which the client is willing and able to bear certain levels of risk measure in terms of cost, quality, time, and other criteria within the client value system. The selected procurement strategy must ensure that risk is transferred to the best parties that can covert the risk/liability to assets.

Table 1, Characteristics of some methods of procurement

\begin{tabular}{|c|c|}
\hline Factor & Characteristics \\
\hline $\begin{array}{l}\text { Build develop and } \\
\text { operate }\end{array}$ & $\begin{array}{l}\text { Consortium receive } \\
\text { concession to finance, design, } \\
\text { construct and operation } \\
\text { project for an agreed time to }\end{array}$ \\
\hline Novation & $\begin{array}{l}\text { Client consultants prepare } \\
\text { initial pre -contract designs } \\
\text { but once contractors selected, } \\
\text { the contractors is responsible } \\
\text { the post-contract design stage. }\end{array}$ \\
\hline Management contracting & $\begin{array}{c}\text { Work packages let to work } \\
\text { contractors and reports } \\
\text { management contractors }\end{array}$ \\
\hline Cost plus contract & $\begin{array}{l}\text { Scope of work not known. } \\
\text { Efficient if client has } \\
\text { experience staff to overseen } \\
\text { the works }\end{array}$ \\
\hline $\begin{array}{l}\text { Build lease operate and } \\
\text { transfer }\end{array}$ & $\begin{array}{l}\text { Private organisation design, } \\
\text { constructs, and operates } \\
\text { facility of leased land. The } \\
\text { facility is return back to } \\
\text { government after a period of } \\
\text { time } \\
\end{array}$ \\
\hline Joint venture & $\begin{array}{l}\text { A partnership of firms to } \\
\text { execute a contract. Each has } \\
\text { liability for their contract }\end{array}$ \\
\hline Build own and operate & $\begin{array}{c}\text { A private firm builds, owns } \\
\text { and operates public structure. } \\
\text { Government sometime } \\
\text { provide some incentives }\end{array}$ \\
\hline Build own transfer & $\begin{array}{l}\text { a private firm receives a } \\
\text { concession to finance, design, } \\
\text { construct, and operate as } \\
\text { define in the contract }\end{array}$ \\
\hline Turnkey & $\begin{array}{l}\text { Contractor/ developer agree } \\
\text { to deliver the completed } \\
\text { project. Once the project start } \\
\text { client has little contribution to } \\
\text { make. A well-defined scope } \\
\text { of is not required }\end{array}$ \\
\hline Unit price contract & $\begin{array}{c}\text { Require complete plans, } \\
\text { specifications. }\end{array}$ \\
\hline
\end{tabular}


Table 1, Characteristics of some methods of procurement (Cont'd)

\begin{tabular}{|c|c|}
\hline Design and build & $\begin{array}{l}\text { Contract design and construct } \\
\text { the facility. Client consultant } \\
\text { advise on contractor selection } \\
\text { and sometime provide some } \\
\text { supervisions of works }\end{array}$ \\
\hline $\begin{array}{l}\text { Construction } \\
\text { management }\end{array}$ & $\begin{array}{l}\text { The construction works } \\
\text { executed by the trade } \\
\text { contractors. Trade contractors' } \\
\text { are overseen by construction } \\
\text { manager. The contractors has } \\
\text { direct contract with clients. }\end{array}$ \\
\hline Prime contracting & $\begin{array}{l}\text { A firm not necessarily in a } \\
\text { contractors organise, coordinate } \\
\text { all parties in a contract thereby } \\
\text { providing single point contact to } \\
\text { client }\end{array}$ \\
\hline Fees contracting & $\begin{array}{l}\text { Operate services for a fee, but } \\
\text { investing in the capital }\end{array}$ \\
\hline $\begin{array}{l}\text { Traditional design, bid } \\
\text { and construct }\end{array}$ & $\begin{array}{l}\text { Design function is separate from } \\
\text { construction function. } \\
\text { Subcontractors report to main } \\
\text { contractors. Scope of work } \\
\text { clearly defined. }\end{array}$ \\
\hline Cost reimbursement & $\begin{array}{c}\text { Scope of work not known of } \\
\text { defined when contract is entered }\end{array}$ \\
\hline $\begin{array}{l}\text { Private finance } \\
\text { initiative }\end{array}$ & $\begin{array}{l}\text { Comprises of some methods } \\
\text { listed here. Collectively PFI is a } \\
\text { method for government works. } \\
\text { In general, a consortium, will } \\
\text { design, delivery and possible } \\
\text { operate the facility for a period. }\end{array}$ \\
\hline Project management & $\begin{array}{c}\text { Direct site supervise is require } \\
\text { but general administrations }\end{array}$ \\
\hline Lump sum contract & $\begin{array}{c}\text { Require a well-defined scope of } \\
\text { work }\end{array}$ \\
\hline
\end{tabular}

Once the need for constructing new projects emerges, arrangement will have to be made on the methods of financing the projects. This could be loans, debentures, stock or forming alliance or partnership with other stakeholders that have similar interests. Based on the first survey conducted by the Chartered Institute of Building (CIOB) into procurement in the construction sector, a major finding from the report indicates that $87 \%$ of respondents belief that good procurement is synonymous with a successful project [14]. The report also suggested that approximately $60 \%$ of the respondents believed that the chosen procurement method determined the success of the projects. Elsewhere, it was found that a suitable ways of reducing the cost of a construction is by selecting a suitable procurement type for the project [15]. The essence of selecting the appropriate procurement strategy is enormous. It guides projects to success. For instance, the procurement strategy/contract arrangement sets out the tasks, rights, obligations, and duties of all parties to the contract. It also includes other important details like the completion time, contract sum, quality of materials and components, and the overall quality standard the project must achieve as well as the level of workmanship. Additionally, it ensures that all obligations are dually and diligently carried out either before, during, or after the completion or the combination of the either. It was noted that by selecting an appropriate procurement strategy, uncertainties can be controlled, risk can be well managed, labour can be planned and standardised [10] and delay, disputes, and conflicts can be minimised if not avoided. However, the traditional procurement system is still the most dominant among the Nigerian clients. Previous studies have addressed the ranking of the dominant procurement in Nigeria $[10,16]$. However, a number of factors require critical examinations in selecting a suitable method for a project. This current study addresses itself to the evaluations of these factorsdeterminant- in the procurement strategy selection by the quantity surveyors. There are various determinants/utility factors for construction procurement selections $[8,17,18$, $19,20,21]$ that have been investigated by previous researchers. But as previously mentioned these studies suffer 'averaging' problems.

\section{The competencies, skills and knowledge of a quantity surveyor}

Quantity surveying is carried out under different names. In countries like the USA, quantity surveying is closely related to cost engineering, while they are also referred to as cost economists or cost consultants in other places. However, quantity surveying is more than any of those names or titles. Perhaps the phrase "quantity surveying" is a catch-up term that hides a multitude of meanings. The services of modern quantity surveyors are required in all sectors of economic endeavour such as the financial, insurance, oil and gas, construction, as well as in the academic sector. The roles that the quantity surveyors perform today have diversified into industries including petrochemical, manufacturing, automobile, mining, telecommunication, shipping, transport, and agriculture. The major impetus for this diversification is the changing requirements of the stakeholders. There is increasing awareness on accountability and transparency [22]. The current business model is pushing the clients to demand for construction to be completed on schedule, within budget, with maximum performance, reliability, safety, and meeting other criteria within their client value system. The clients are pushing the construction industry to take a cue from the automobile, banking and electronic industries that move with time.

The Royal Institute of Chartered Surveyors considered the quantity surveyors as the cost managers of construction that are initially involved with the capital expenditure phase of a building or facility, which is the feasibility, design, and construction phases and can be involved with the extension, refurbishment, maintenance, and demolition of a facility including process engineering, such as chemical engineering plants or oil rigs, and will understand all aspects of construction over the whole life of a building or facility [23]. But while this definition/description is incomplete, it provides an indicative on what quantity surveyors represent. For instance, quantity surveyors provide advice on the strategic planning of a project. For a construction work, 
this advice affects clients' decisions on whether to construct or not, and if the client decides to construct what effect costs have on other criteria within the clients/users value systems. Specifically, the advice provided includes the selection of procurement strategies as well as method of contracts.

The courses contents of the quantity surveyors reflect their capabilities and expertise in providing advice on the procurement issues. For instance, even under the traditional procurement system where the quantity surveyor is not usually the lead or prime consultant, all other members of the team, including the client relates their valuable information to the quantity surveyor to enable the production of accurate estimates to make meaningful contributions towards the successful completion of construction facilities $[22,24,25,26]$ Quantity surveyors by their training and experience in contractual, economics, and costing matters, plus the technical knowledge in construction processes and activities are better informed on the procurement processes and procedures.

\section{Outline of research design}

The methodology of the study combines literature review and survey questionnaire. A broad reviews of literature suggested that there are various types of determinants for procurement strategies whether for new construction, maintenance, refurbishment, conversion, adaption and, for operational purposes only. Therefore, to achieve the aim of this study, 18 determinants for procurement strategy selection were compiled and addressed to respondents to measure. The survey was developed from literatures [18, 19, 20, 22, 24, 26, 27] and the authors' own experiences. Primary data is collected based on convenience sampling. In convenience sampling, a survey is administered on the respondents who are accessible, available or willing to participate. It is an appropriate method where sufficient information on population size is not available but like other nonprobability sampling, its findings may not be generalisable. However, if the respondents are carefully selected with sufficient sample size, the findings are representative [28]. Primarily data for this survey was administered through an online survey. The survey commenced in November 2014 through to April 2015. The questionnaire was divided into two parts. The first part seeks to capture the respondent's profiles while the second part measures procurement strategy selection with respect to the quantity surveyors. The survey was mainly close ended, but empty spaces were provided for respondents to add additional determinants they considered significant not listed in the form.

Respondents were asked based on their current experience, to place a tick on the extent that each of the 'determinants' is significant in the selection of procurement strategy for a construction work on a five continuum scale; where 5 denotes 'extremely often', and 1 denotes 'not often'. 2, 3 and 4 are located in between. For interpretation, the lowest possible score is 0 (zero) and the highest possible score is 1 (one). Simply put, the closer to 1 the higher the extent at which a determinant influences method of procurement selection. The mode technique was used to analyze the demography of the respondents. The measurements of the determinants are displayed in frequencies but the rating of the reasons is determined by 'average relative index' (ARI). The ARI is based on the aggregate weighting of the initial frequency score of each constructs (i.e. factors, criteria, items et al.)

$$
A R I=\frac{\sum_{i=0}^{5} a_{i} x_{i}}{5 \sum_{i=0}^{5} x_{i}}
$$

Where $a_{i}$ is the index of a group; constant expressing the weight given to the group; $x i$ is the frequency of response; $\mathrm{i}=1,2,3,4,5$ and described as below: $x_{1}, x_{2}, x_{3}, x_{4}, x_{5}$ are the frequencies of the response corresponding to $a_{1}=1, a_{2}=2, a_{3}=3, a_{4}=4, a_{5}=5$, respectively. The determinant with the highest mean score is considered as the dominant. The mode technique was used to analyse the demographic of the respondents.

\section{Results and interpretations}

\subsection{Captions/numbering}

A total of 33 useable responses were received and analysed for this study. The profiles of the respondents are shown in Tables 2 through 4 and Figures 1 and 2. As may be seen, the majority of the respondents held MSc. (Table 1) many have Bachelor of technology, while a substantial number had HND. Figure 1 indicates that most of the responding quantity surveyors are from the consulting firms with only five of the 33 quantity surveyors having worked for contracting companies while the remainder worked for publicly owned organisations. Most of the respondents were occupying strategic positions in their various organisations (Figure 2 ). For instance, $40 \%$ (13) of the respondents occupy the position of project managers while seven or $21 \%$ held senior quantity surveyor potions. Four are partners and three are principal partners in the organisations.

Table 2, Respondent's academic qualification.

\begin{tabular}{|c|c|c|}
\hline Qualification & Frequency & Percentage \\
\hline BTech. & 9 & 27.3 \\
\hline HND & 6 & 18.2 \\
\hline BSc. & 2 & 6.1 \\
\hline MSc. & 13 & 39.4 \\
\hline PgD & 3 & 9.1 \\
\hline Total & 33 & 100.0 \\
\hline
\end{tabular}




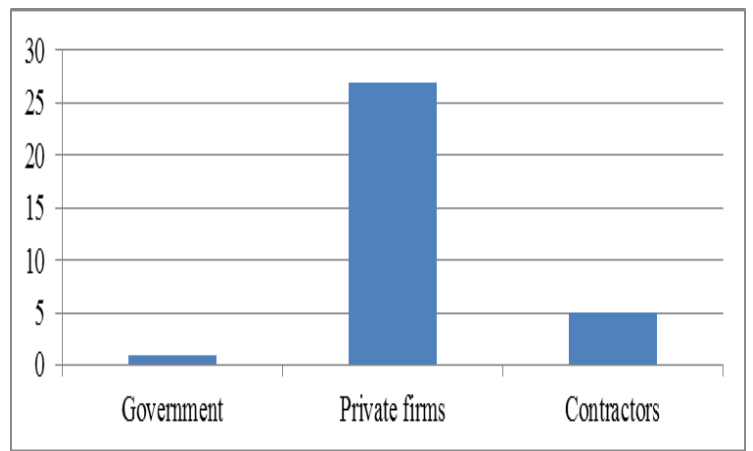

Figure 1, Distribution of respondent's organisation.

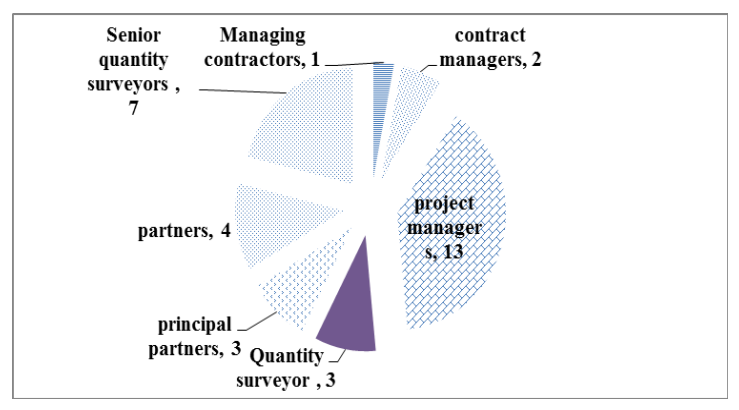

Figure 2, Distribution of respondent's position (\%).

In terms of working experience, $75 \%$ ( 25 to be exact) of the respondents have worked for more than five years (Table 3), with more than $40 \%$ having more than 10 years' experience in the construction sector. The mean score for the working experience is 2.39 and the standard deviation is 1.14 . The mean score and standard deviation for the numbers of projects respondents have completed in the last ten years are 1.9 and 1.13 respectively. Close to $55 \%$ of the responding participants' organisations have completed more than one construction works in a year (see Table 4). Although the turnovers of the organisations are not investigated, but considering the working experience and positions, these are big projects. Further, another aspect of the survey found that the type of works involved by the respondents include construction of buildings, civil engineering, building services, railways, airports, and petrochemical plants.

Table 3, Distribution of respondent's industrial experience.

\begin{tabular}{|c|c|c|}
\hline Qualification & Frequency & Percentage \\
\hline Not more than five & 8 & 24.2 \\
\hline Five to ten & 12 & 36.4 \\
\hline Ten to fifteen & 6 & 18.2 \\
\hline Fifteen to twenty & 6 & 18.2 \\
\hline Twenty and above & 1 & 3.0 \\
\hline Total & 33 & 100.0 \\
\hline
\end{tabular}

Table 4, Number of projects completed in the last 10 years

\begin{tabular}{|c|c|c|}
\hline Qualification & Frequency & Percentage \\
\hline Not more than ten & 15 & 45.5 \\
\hline Ten to twenty & 11 & 33.3 \\
\hline Twenty to thirty & 4 & 12.1 \\
\hline Thirty to forty & 1 & 3.0 \\
\hline Forty and above & 2 & 6.1 \\
\hline Total & 33 & 100.0 \\
\hline
\end{tabular}

On the basis of these profiles, it is evidenced that the respondents have capabilities and experience to provide valid and unbiased information on the Nigerian construction sector.

\subsection{Factors that determine procurements strategy's selection}

The following sections present the measurements of the determinants of selection of an appropriate procurement strategy. In order to determine the strength of the data, reliability and validity tests were performed. The reliability test results indicate that the Cronbach's alpha for all the roles are very satisfactory, ranges from 0.810 to 0.834 (Table 6). The validity test, using the 'Commonalities', produced values that ranges from 0.542 to 0.843 . In general, if the alpha reliability or validity test is above 0.50 , it is sufficient to consider that the construct (factor) is valid or reliable. Further, as may be seen in Table 5, there is a relationship between all the determinants with Bartlett's Test (0.0001). However, there exist some high correlation between the determinants; with the KMO of 0.412 typically KMO value should exceed 0.5 . A reason for this might be the sample size. Overtly, these statistics suggest that the data was drawn from a similar population or simply that the respondents have similar experience. Consequently, the data is both valid and reliable and thus the results are representative.

Table 5, Results of KMO and Bartlett's Test.

\begin{tabular}{|l|c|c|}
\hline \multicolumn{2}{|c|}{$\begin{array}{c}\text { Kaiser-Meyer-Olkin Measure of Sampling } \\
\text { Adequacy. }\end{array}$} & 0.412 \\
\hline \multirow{2}{*}{$\begin{array}{l}\text { Bartlett's Test of } \\
\text { Sphericity }\end{array}$} & Approx. Chi-Square & 322.752 \\
\cline { 2 - 3 } & $\mathrm{df}$ & 153.000 \\
\cline { 2 - 3 } & Sig. & 0.000 \\
\hline
\end{tabular}


Table 6, Standard deviation, Validity and Reliability Results

\begin{tabular}{|c|c|c|c|}
\hline Factor & $\begin{array}{l}\text { Standard } \\
\text { deviation }\end{array}$ & Validity & Reliability \\
\hline Type of client & 0.66 & 0.542 & 0.822 \\
\hline Design input & 0.73 & 0.804 & 0.831 \\
\hline $\begin{array}{l}\text { Management } \\
\text { team }\end{array}$ & 0.77 & 0.537 & 0.827 \\
\hline $\begin{array}{c}\text { Availability of } \\
\text { resources }\end{array}$ & 0.82 & 0.683 & 0.819 \\
\hline $\begin{array}{c}\text { Type of risk in the } \\
\text { projects }\end{array}$ & 0.89 & 0.693 & 0.817 \\
\hline $\begin{array}{l}\text { Client ability and } \\
\text { willingness to } \\
\text { carry risk }\end{array}$ & 0.86 & 0.810 & 0.828 \\
\hline $\begin{array}{c}\text { Legal } \\
\text { requirements }\end{array}$ & 1.10 & 0.738 & 0.834 \\
\hline $\begin{array}{c}\text { Size of the } \\
\text { projects }\end{array}$ & 0.76 & 0.589 & 0.829 \\
\hline $\begin{array}{c}\text { Continuity of the } \\
\text { project }\end{array}$ & 0.88 & 0.859 & 0.818 \\
\hline $\begin{array}{c}\text { Time available } \\
\text { until completion }\end{array}$ & 1.12 & 0.835 & 0.826 \\
\hline $\begin{array}{c}\text { Requirements of } \\
\text { stakeholders }\end{array}$ & 0.79 & 0.809 & 0.831 \\
\hline $\begin{array}{l}\text { Government } \\
\text { policy }\end{array}$ & 0.97 & 0.689 & 0.817 \\
\hline $\begin{array}{l}\text { The client's } \\
\text { experience }\end{array}$ & 0.94 & 0.843 & 0.833 \\
\hline $\begin{array}{l}\text { client insistence } \\
\text { on knowing the } \\
\text { expected price }\end{array}$ & 0.98 & 0.743 & 0.826 \\
\hline $\begin{array}{c}\text { Contractual } \\
\text { method use to the } \\
\text { project }\end{array}$ & 0.82 & 0.802 & 0.816 \\
\hline $\begin{array}{l}\text { Requirement of } \\
\text { funding } \\
\text { organisation }\end{array}$ & 0.92 & 0.638 & 0.810 \\
\hline $\begin{array}{c}\text { Information } \\
\text { available at the } \\
\text { conceptual stage }\end{array}$ & 0.96 & 0.843 & 0.823 \\
\hline $\begin{array}{c}\text { Expected } \\
\text { completion date }\end{array}$ & 1.11 & 0.788 & 0.814 \\
\hline
\end{tabular}

Table 7 contains the descriptive results on determinants of the selection of procurement strategy. Overtly, $28.6 \%$ of the quantity surveyors measured that they considered the entire determinants extremely often, while $41.25 \%$ of them considered the determinants very often. While $23.57 \%$ often considered the determinants, less than $7 \%$ of the quantity surveyors seldom considered the determinants. The cumulative average weightage is 0.780 . The index ranges from 0.679 for legal requirement to 0.8798 for the type of client respectively.

Because of space constraint, detail explanation on each of the determinant will not be provided. Among the various types of procurement options available to a client towards achieving best value, only one of the procurement strategies is suitable for a particular set of client's requirements but not the others. For instance, some procurement strategies placed greater emphasis on a criterion or on some particular criteria within the client value system. As an illustration, the traditional strategy is most suitable for a project where time is not an essential priority. Under this strategy, tender is usually selected on the basis of the lowest tender price. However, time is an essential feature of any project, time also makes mess of any cost estimate and there is not a project without time limitation. Modern procurement strategies strive on the need to overlap time. Therefore, it becomes imperative that the determinants for the procurement selections are known as a prerequisite otherwise the wrong determinants/s would be selected automatically leading to a wrong strategy consequently leading to poor construction delivery.

Though it is possible to rank the determinants in terms of the weighting index, detailed examinations of the indices suggest that the variability among the determinants is quite close. Therefore, any attempt to rank the determinants might not provide any useful interpretations in terms of ranking other than mere number. Hence, we prefer not to be mechanistic with the interpretations. Rather than focus on the figures, we dwell on the reason behind the figure. Hence, a more meaningful and plausible interpretation is that all the determinants plays very significant roles in the determination of a particular procurement strategy for construction project. However, these findings are contrary to the findings of Mathonsi and Thwala [7], Songer et al. [29], Oluwole [30], and Hashim et al. [31].

Researchers are able to detect significance differences in the weightages with respect to the determinants. Two major reasons could account for this. First, it could be that the stakeholders have a different understanding with the meaning of procurement strategies and their associated issues. The second reason could be that the clients are now more demanding compared to how they used to measure value for their money. Both reasons are insightful. While there is sufficient literature to support the claim that construction clients are very demanding and are concerned about their investments [16, 20], in the context of these findings, it is very unlikely that the reason for this is because of the clients demanding aspect.

The major reason is very much concerned with the structure of the respondents, whereby the average of the responses will be compiled thereby suppressing that of the others. An exploratory factor analysis conducted produced the results in Table 8. A 0.50 factor loading cutoff point was adopted thus eliminating project size and funding organisations' requirement. 
Table 7, Distribution of the determinants of selections of procurement strategy

\begin{tabular}{|c|c|c|c|c|c|c|}
\hline Determinant & $\mathbf{5}$ & $\mathbf{4}$ & $\mathbf{3}$ & $\mathbf{2}$ & $\mathbf{1}$ & $\mathbf{I n d e x}$ \\
\hline Type of client & 17 & 12 & 4 & 0 & 0 & 0.8798 \\
\hline Design input & 8 & 16 & 9 & 0 & 0 & 0.7939 \\
\hline Management team & 9 & 17 & 6 & 1 & 0 & 0.8061 \\
\hline Availability of resources & 14 & 13 & 5 & 1 & 0 & 0.8424 \\
\hline Type of risk in the projects & 5 & 16 & 8 & 4 & 0 & 0.7333 \\
\hline Client ability and willingness to carry risk & 6 & 17 & 7 & 3 & 0 & 0.7576 \\
\hline Legal requirements & 4 & 13 & 10 & 4 & 2 & 0.6788 \\
\hline Size of the projects & 15 & 12 & 6 & 0 & 0 & 0.8546 \\
\hline Continuity of the project [programme management] & 9 & 14 & 8 & 2 & 0 & 0.7818 \\
\hline Time available until completion & 10 & 14 & 5 & 2 & 2 & 0.7697 \\
\hline Requirements of stakeholders & 3 & 15 & 12 & 3 & 0 & 0.7091 \\
\hline Government policy & 13 & 9 & 9 & 2 & 0 & 0.8000 \\
\hline The client's experience & 5 & 11 & 14 & 2 & 1 & 0.7030 \\
\hline Information available at the conceptual stage & 13 & 10 & 9 & 1 & 0 & 0.8121 \\
\hline Expected completion date & 12 & 14 & 6 & 1 & 0 & 0.8242 \\
\hline Requirement of funding organisation & 8 & 17 & 6 & 1 & 1 & 0.7818 \\
\hline client insistence on knowing the expected price & 13 & 10 & 1 & 1 & 0.7576 \\
\hline Contractual method use to the project & 6 & 4 & 1 & 0.7576 \\
\hline
\end{tabular}

However, the determinants can be explained in terms of methods of procurement. In the procurement of projects, each of the stakeholders comes into the arrangement with the different mission and vision. For instance the while government comes into such arrangement in order to meets their social / community responsibilities the banks enter into such venture majorly to maximize their profits. Other stakeholders will also come in if the project is economically viable and feasible. The decisions to enter into such arrangement particularly in case of the government depends on factors including capital cost, maintenance cost, replacement, depreciation, expertise and operating cost of the projects. As an illustration, the PFI came on board because of the financial shortages arising from governments' commitments elsewhere. Because of public interests, governments have over the years preferred the traditional procurement because they want to be seen to protect public money. For the private client, this has little considerations. However, public clients also now prefer to acquire projects through modern procurement strategies to the traditional strategies because of shortage of funds and that public facilities are not well managed if the hand of the government agencies or subsidiaries. Similarly inexperience clients whether private or private, possibly opt for the type of procurements required complete scope of works. The nature and of projects and experience of the clients will also dictate whether the procurement method to select should expose the clients to risk. Moving forward, as may be seen it is possible to categorise the determinants into 6 major headings accounting for some $73.591 \%$ cumulative total variance explained. The headings are client's factor (1); contractual factor (2); contract factor (3); project factor (4); external factor (5); and risk factor (6). 
Table 8, Rotated Component Matrix

\begin{tabular}{|c|c|c|c|c|c|c|}
\hline \multirow[t]{2}{*}{ Factor } & \multicolumn{6}{|c|}{ Component } \\
\hline & 1 & 2 & 3 & 4 & 5 & 6 \\
\hline Type of client & 0.665 & & & & & \\
\hline Design input & & & 0.787 & & & \\
\hline Management team & & & 0.704 & & & \\
\hline Availability of resources & 0.687 & & & & & \\
\hline Type of risk in the projects & 0.680 & & & & & \\
\hline Client ability and willingness to carry risk & & & & & & 0.827 \\
\hline Legal requirements & & 0.765 & & & & \\
\hline Size of the projects & & & 0.406 & & & -0.457 \\
\hline Continuity of the project[programme management] & 0.584 & & & & 0.595 & \\
\hline Time available until completion & 0.695 & & & 0.401 & & \\
\hline Requirements of stakeholders & & & & & 0.894 & \\
\hline Government policy & & & 0.646 & & & \\
\hline The client's experience & & 0.579 & & -0.520 & & \\
\hline client insistence on knowing the expected price & 0.412 & & & 0.652 & & \\
\hline Contractual method use to the project & & 0.687 & 0.409 & & & \\
\hline Requirement of funding organisation & 0.472 & & 0.409 & 0.445 & & \\
\hline Quality of available information at the conceptual stage & & 0.886 & & & & \\
\hline Expected completion date & & & & 0.776 & & \\
\hline
\end{tabular}

\section{Conclusion}

The paper re-appraised the construction procurement strategies in the Nigerian construction industry. Whichever the chosen procurement strategy selected, the client's value system should be used as a proof screen. It seems there is no simple or hard and fast rule for the selection of the most appropriate contract types for a project. It seems obvious however, that there are simple frameworks that can facilitate the selection of contract type that can facilitate the achievement of client value system. In the future, a research on the various ways of evaluating the determining factors will be conducted. This is critical to the entire process of procurement selection. Notwithstanding, having knowledge on the determinant would not be sufficient except if the correct tool is used to determine the correct determinants for a project. It is suspected that the tools currently used to evaluate and determine procurement are flawed. Hence, there is a need to clearly re-examine the method for identifying the client's value systems.

\section{References}

1. Olanrewaju, A. and Anavhe, J. P., Issues in the construction procurement process. In Saha, S., Zhang, Y., Yazdani, S., and Singh, A. (2015) (eds.) Implementing Innovative Ideas in Structural Engineering and Project Management, Sydney, pp1341-1346.

2. Egan, J., Rethinking Construction, London: Department of the Environment, transport and region HMSO, (1998).
3. Latham, M. (1994).Constructing the Team: Final Report - Joint Review of Procurement and Contractual Arrangements in the UK: HMSO, UK

4. Construction 2025, Industrial Strategy: government and industry in partnership, (2013) Available at http://www.ecobuild.co.uk/files/industry_strategy_to 2025.pdf. [accessed on March, 2015]

5. Dada, O. M., Predictors of Procurement Selection: An Investigation of Traditional and Integrated Methods in Nigeria. Journal of Construction in Developing Countries, 17(1) 69-83, (2012).

6. Ojo, S. O. and Ikpo, I. J., Determining the Performance of Procurement Methods against Selection Criteria using Outranking - Satisfying Methodology. Journal of Engineering, Project, and Production Management, 3(2), 74-84(2013).

7. Mathonsi, M. D. and Thwala, W. D., Factors influencing the selection of procurement systems in the South African construction industry African Journal of Business Management Vol. 6(10), pp. 3583-3594, 14 March, (2012)

8. Love, P. E. D, Skitmore M. and Earl, G., Selecting an appropriate procurement method for the construction process: an empirical study. Construction Management and Economics, 16(2):pp. 221-233, (1998).

9. NBS (National Bureau of Statistiques) Nigerian Construction Sector: Summary Report; 2010-2012, (2015) Available at at file://C:/Users/olanrewaju/Downloads/nbs\%20Niger ian\%20Construction\%20report\%202010_2012.pdf [accessed on 10 March 2015]

10. Olanrewaju, A. A. and Khairuddin, A.,Identifying the Dominant Procurement Strategies in the Nigerian

\footnotetext{
${ }^{\mathrm{a}}$ Corresponding author: abdullateef.olanrewaju@ymail.com
} 
construction industry. In: Proceedings of the Management in Construction Researchers Conference Malaysia (MICRA). Shah Alam, Malaysia, 28th 289th August, (2007).

11. Kelly, J., Male, S. and Graham, D., Value Management of Construction Projects, Blackwell, Oxford, (2004).

12. Perry, J. G. (1985), The development of contract strategies for construction projects. Ph.D. thesis, University of Manchester, cited in Cheung, S. I., Lam, T. I and Leung, M.Y (2001) An analytical hierarchy process based procurement selection method, Journal Construction Management and Economics, 19:4, pp427 - 437

13. Olanrewaju, A. A and Anavhe, P. J., Appraisal of Construction Procurement Strategies in Nigeria, In: Ahmed, M. S., Farooqui, R. U., Azhar, S., Shah, A., Lodi, H. S and Smith, A N., (Ed.) Procs. of Third International Conference On Construction In Developing Countries "Advancing Civil, Architectural And Construction Engineering \& Management" (ICCIDC-III). July 4 - 6, 2012, Thailand, pp 195 - 201, (2012),

14. The Chartered Institute of Building (CIOB) A Report exploring procurement in the construction industry, (2010).

15. Ahuja, H. N., and Walsh, M. A., Construction Management and Engineering: Successful Methods in Cost Engineering. Canada: John Wiley \& Son Inc.

16. Olanrewaju, A. A and Anahve, P. J (2013), Delay Factors in the Nigerian Construction Industry, In Proceeding of COBRA 2013. New Delhi, September, $10-12$

17. Love, E.D. P., Davis, R. P., Edwards, J. D. and Baccarini, D (2008) Uncertainty avoidance: public sector clients and procurement selection, International Journal of Public Sector Management, Vol. 21 Iss. 7 pp. $753-776$.

18. Davis, P., Love P., and Baccarini, D., Building Procurement Methods. Research Program: C Deliver and Management of Built Assets Project: 2006-034C., (2008). http://www.constructioninnovation.info/images/pdfs/Research_library/Resear chLibraryC/2006-034-C/reports/Report_Building_Procurement_Methods.pdf.

19. Ramus, J., Birchall, S. and Griffiths, P. Contract practice for surveyors, 4 th ed. Oxford: Butterworth Heinemann (2006).

20. Cartlidge, D., Procurement for built assets, Elsevier Butterworth - Heinemann, Oxford (2007).

21. National Economic Development Office (NEDO) (1985) Think About Building. NEDC, London.

22. Cartlidge, D., New Aspects of Quantity Surveying Practice, Oxford: Taylor \& Francis, (2011).

23. (RICS (Royal Institution of Chartered Surveyors) Glossary of surveying services Brief definitions of surveying services to help you find the right surveyor (2015). http://www.ricsfirms.com/glossary

24. Seeley, H. I (1997), Quantity Surveying Practice, London, 2nd Ed. Macmillan Press Ltd.
25. Ashworth, A., Hogg, K. and Higgs, C., Willis's Practice and Procedure for the Quantity Surveyor. John Wiley and Sons, Ltd. West Sussex(2103).

26. Marsh, C., Building services procurement. Spon Press, Taylor and Francis Group, London and New York(2003).

27. Towey, D., Construction quantity surveying: a practical guide for the contractor's QS, WileyBlackwell, UK, (2012).

28. Sekaran, U. Bougie, R., Research methods for business: a skill building approach. 5th Edn, John Wiley and Sons, Limited, UK(2010)

29. Songer, D. A., Molenaar, R. K, and Robinson, D. G., Selection Factors and Success Criteria for DesignBuild in the U.S. and U.K. (1997) http://www.colorado.edu/engineering/civil/db

30. Oluwole, A. A. Evaluation of Building Project Procurement Strategies (A case Study of Ondo State, Nigeria). International Research Journal of Engineering and Technology, Volume: 02 Issue: 05, (2015)

31. Hashim, M., Li, Y. C. M., Yin, C. N., Hooi, S. N., Heng, M. S., Yong, L. T (2006) Factors influencing the selection of procurement systems by clients, International Conference on Construction Industry, Padang, Indonesia, 21st June - 25th June 2006. 